\title{
The Relationship between Test Anxiety, Epistemological Beliefs and Problem Solving among Students
}

\author{
Vali Mehdinezhad ${ }^{1 *}$, Zeinab Bamari ${ }^{2}$ \\ 1Department of Education, University of Sistan and Baluchestan \{valmeh@ped.usb.ac.ir \\ ${ }^{2}$ University of Sistan and Baluchestan \{z bamari64@yahoo.com\} \\ Received on 13 August; revised on 1 September; accepted on 22 September; published on 15 January \\ DOI: 10.7821/naer.2015.1.97
}

\begin{abstract}
The purpose of this study was to investigate the test anxiety, epistemological beliefs and problem solving among students. The target population of the current research was all the students of University of Sistan and Baluchestan in the academic year 20132014 and the number of the sample was 375 . They were selected using a classified and simple random method. The main tools to collect data were three questionnaires. The test anxiety questionnaire by Abolqasemi et al. (1996), epistemological beliefs questionnaire by Schommer (1998), and Patio problem-solving questionnaire (2002) were used. The reliability of these questionnaires was calculated through Cronbach's Alpha test as $0.93,0.75$ and 0.88 . To test the research questions, single sample t-test, independent $t$ and Pearson correlative coefficient were adopted using SPSS software, version 20. The results showed that students have relatively high-test anxiety. It was also shown that they have relatively good epistemological beliefs. The students' status to solve the problems is also satisfactory to some extent. There is a positive and significant relationship between test anxiety and epistemological beliefs at low level. But no statistically meaningful relationship was noticed between test anxiety and problem solving. Meanwhile the results showed that there is a negative and meaningful relationship at low level between epistemological beliefs and problem solving.
\end{abstract}

KEYWORDS: TAST ANXIETY, EPISTEMOLOGICAL BELIEFS, PROBLEM SOLVING

\section{INTRODUCTION}

Test anxiety is a common phenomenon among students and is considered one of the problems of the educational system. Due to the extensive effect of anxiety and its negative consequences, the sources of anxiety and its effects should be specified (FathiAshtiani \& Qolivand, 2002). Test anxiety has close relation with educational performance and progress and even the future performance of millions of school and university students (Kivimaki, 1995). Test anxiety is a common type of performance anxiety and 10 to $20 \%$ of the school and university students suffer from it (Sargolzaei, Fayazi-Bordbar, Samari, \& Shakiba, 2003). It is also a general expression and is known as a social anxiety or fear that makes the individual feel doubtful about his abilities, and its consequence is a reduction of ability

\footnotetext{
${ }^{*}$ To whom correspondence should be addressed:

University of Sistan and Baluchestan, Zahedan

University Boulevard

Zahedan, Iran
}

to confront test situations and those where the individual is exposed to assessment. It requires problem-solving; therefore, it could be said that the person suffering from anxiety knows the answers to the test questions, but the degree of test anxiety prevent him from using his knowledge (Sargolzaei, et al., 2003).

Systematic research in the area of anxiety as a cognitiveprovocative phenomenon refers to the studies conducted by Mandler and Sarason (1952). Morris and Libert in the 1996 and Spiel Berger in the 1980 raised the two important parameters, i.e., concern and provocation for test anxiety (Yousefi, Habibi, \& Mohammadkhani, 2013). The parameter of concern refers to cognitive activities irrelevant to obligation that consists of high cognitive concern about performance, consequences of failure resulting from testing thoughts vis-à-vis self-humiliation and blaming, assessment of one's ability in comparison with others, negative expectations of the performance and self-statement in a negative way and the parameter of provocation refers to autonomous physiological reactions such as palpitation, butterfly in one's stomach, headache, perspiration, etc. (MehrabizadehHonarmand, Abolqasemi, Najjarian, \& Shekarkan, 2000). The effective factors that create the test anxiety could be classified into three main factors, i.e., personality factors (low selfconfidence, ban on external control, general anxiety of selfefficiency, unsuitable studying skills and learnt disappointment), educational centre-related factors (difficult lessons and tests, teacher's untimely expectations, time restrictions, unsuitable test environment, unsuitable light and unsuitable disturbing factors such as noise) and family-related factors (methods of raising children, parents' excess demands, punishment and blaming, encouragement and socio-economic situation).

The first studies regarding test anxiety started in 1994 (Stober \& Pekrun, 2004), but serious studies regarding test anxiety started as one of the important cognitive-provocative variables by Mandler and Sarason (1952). From then to 1980s the studies regarding test anxiety reached the climax (Sobhi-Qaramaleki, Rasoulzadeh-Tabatabaei, Azad-Fallah, \& Fathi-Ashtiani, 2008) including the ones conducted by Zioyesk et al., in the 2009 that studied the role of cognitive beliefs to adapt with special conditions such as test anxiety. Their sample consisted of 440 students. The results showed that negative cognitive variables including personal beliefs dealt with lack of control, existing risk, shortage of incentive and enthusiasm as well as autonomous thoughts that could define students' test anxiety in the best possible.

Nowadays, educational psychologists and experts seek new ideas about the nature and development of cognition 
increasingly and how epistemological ideas affect thoughts and reasoning. Epistemological thoughts are the students' beliefs regarding the nature of knowledge that affect the personal thinking of the educational processes. In other words, epistemological beliefs are the thinking that individuals have about knowing. These beliefs form part of the cognitive processes, thoughts and reasoning and affect the learners' educational performance. Individual beliefs regarding the nature of knowledge, learning and epistemology affect all aspects of the students' daily life, particularly his learning and educational progress (Schommer, 1993). What is meant by epistemological beliefs refers the person's thoughts about the nature of knowledge (Hofer \& Pintrich, 1997; Kardash \& Scholes, 1996) that has by itself relatively different independent aspects from each other, and five more were approved experimentally, i.e., 1) Simplicity of knowledge, 2) Certainty of knowledge, 3) Source of knowledge, 4) Inherent ability to learn, and 5) Rapid learning.

The knowledge-related beliefs might affect the personal imagination of educational processes and the necessary activities to complete obligations, in other words, they form educational behaviour. Nowadays, epistemological beliefs are considered as an important cognitive structure in learning, and education provides a suitable understanding to find out how knowledge is made by individuals (Hofer, 2000). In fact, epistemological beliefs reflect the individual thoughts regarding questions such as knowledge. How it is gained. What credibility degree of knowledge is? What criteria and restrictions exist for knowledge? This one is separate from learner or it is only gained by qualified and expert individuals or it is obtained by interaction with experts and learners, taking the educational areas into consideration (Ravindran, Grene, \& Debacker, 2000; Hofer \& Pintrich, 1997). Through the vast studies conducted by Hofer and Pintrich (Filisetti, 2003) regarding the background of cognitive epistemology, three major waves or currents could be identified and used to distinguish psychological studies about epistemology: The first wave about Perry's study (1981) showed that the growth of epistemological beliefs is studied over time. The second wave studied the ways that affect epistemological beliefs on thought and reasoning (King \& Kitchener, 1994). The third wave studied the beliefs as the epistemological and learning structure (Schommer, 1990). According to Perry's theory from (1981), many studies were conducted to understand the epistemological beliefs of university and school students and teachers. Conley, Pintrich, Vekir, \& Harrison (2004) studied the university students' epistemological beliefs and found out that those concerning source and certainty of knowledge develop during the academic year. But some of them have a developing trend. The nature of individual beliefs about knowledge and knowing changes during the teenage period.

Considering the current conditions of the world and the remarkable development of different technologies, particularly telecommunication and information, one might think that education should merely concentrate particularly on using and training users to make suitable use of technology, but holding and using this technology in the world of education will not open horizons to the human beings in the future. In the current world, the main issue is to train humans to think themselves. Nowadays the learners should acquire increasingly the thinking skills for proper decision-making and solving complicated problems in order to confront the wonderful developments of the $21^{\text {st }}$ century. Many experts such as Anish, Paul, and Lipmann believe that one of the main goals of education is to train thinking human beings (Shaabani, 2003). The method to solve the cuestion is a useful means to confront many situational problems. Teaching skills to solve different situations is also a logical and regular approach that helps and trains the individuals confront the anxiety-creating conditions and states and other scenarios (Shahbazi, Heidari, \& Ali Sheikhi, 2011). The method to sort out a problem is a suitable means to confront many situational ones and the training to solve it is also a logical and regular approach to help and train an individual to confront the stress-making conditions, states and other situations (Shahbazi, Heidari, \& Ali Sheikhi, 2011). The method to solve the problem is in fact a type of active learning method and has five stages: Identification and definition of the problem, collection of information, preliminary conclusion, testing results, assessment and decision-making (Meyers, 2004, p. 17). Kohler is one of the Gestalt psychology founders that focused on solving the problem. He believed that difficulties cause the individual's cognitive balance to be distorted and that the individual intends to remove it. It means that the issue makes the individual to become active to solve the problem and to get back a cognitive balance again. He believed that individuals assess the issues and study all aspects and conditions to be able to obtain the response to the issue in form of knowledge sparkles (Glover \& Bruning, 2001: 211). Anxiety threatens testing the students' psychological health and has negative effect on their efficiency, emergence of talent, personality structure and social identity and could have negative effect on their educational progress and optimal performance, particularly when assessing and evaluating it as one of the overall and problem-making phenomena among the university and school students.

As indicated above, very little research on the relationship between the three variables of test anxiety, epistemological beliefs and problem solving is done. The research results can be achieved when two variables have been examined. For example, the findings Gholami Lavasane, Mellat and Karamatdost (2009) about the role of epistemological beliefs in regulation of learning with regards to the mediating role of motivational constructs, confirmed the significant direct effects of epistemological beliefs on motivational constructs (test anxiety). In this regard, Koksal (2011) in a study of the relationship between components of epistemological beliefs and self-regulation (selfefficacy and test-anxiety) on learning biology, was found that only the belief about "existence of one truth" was a significant predictor of test anxiety while there was no epistemological predictor of self-efficacy. In another study, Hannon (2012) to determine which cognitive/learning (working memory, knowledge integration, epistemic belief of learning) or social/personality factors (test anxiety, performance-avoidance goals) have found the same results that other researchers.

In response there is any relationship between test anxiety and problem solving? The study results showed that a marginal linear relationship whereas test anxiety had almost no relationship with the performance on the non-routine mathematical problem solving test (Yeo Kai Kow, 2005). The findings of many studies about the epistemological beliefs and problem solving significant differences were found on the problem solving skills in terms of epistemological beliefs (Aksan \& Sozer, 2007). Moreover, according to Öngen, (2003) epistemological beliefs are considered to be in relation with studying skills and higher cognition level (where problem solving occurs) as it affects the decisions on finding the correct strategies in order to cope with the challenging nature o the 
Table 1. Reliability Coefficient of Research Questionnaires

\begin{tabular}{|c|c|c|c|}
\hline \multicolumn{2}{|c|}{ Questionnaires } & No. of speeches & Reliability Coefficient \\
\hline \multicolumn{2}{|c|}{ Test Anxiety } & 25 & 0.93 \\
\hline \multirow{5}{*}{ Epistemological Beliefs } & Simple knowledge & 8 & 0.79 \\
\hline & Definite knowledge & 7 & 0.72 \\
\hline & Inherent ability to learn & 7 & 0.71 \\
\hline & Ability to know everything & 5 & 0.69 \\
\hline & Rapid learning ability & 5 & 0.75 \\
\hline \multirow{5}{*}{ Problem-Solving } & Total & 32 & 0.75 \\
\hline & Clarification of issue & 7 & 0.84 \\
\hline & Production of ideas & 9 & 0.73 \\
\hline & Development of solutions & 7 & 0.80 \\
\hline & Implementation of programs & 7 & 0.76 \\
\hline & & 30 & 0.88 \\
\hline
\end{tabular}

mental functions. Oh and Jonassen† (2007) found out a multiple regression was conducted to determine whether any of the five epistemological factors affected the problem-solving process. A stepwise multiple regression identified Omniscient Authority as the strongest predictor of the performance of solution verification.

Erdem (2007) examined the relationship between test anxieties and the epistemological beliefs and problem-solving beliefs of students on a general chemistry course. The results of the Pearson correlation analysis showed a negatively relationship between epistemological beliefs and problemsolving beliefs, while there was no statistically relationship between test anxiety and epistemological beliefs. Considering the current study aims at studying the relationship between test anxiety and epistemological beliefs and problem-solving among the students, the following questions are raised and studied:

- How is the situation of text anxiety, epistemological beliefs and ability to solve problems among students?

- Is there any relationship between test anxiety, epistemological beliefs and ability to solve problems among students?

- Is there any difference among students with regard to test anxiety, epistemological beliefs and problem solving as far as their gender, age, major and educational degree is concerned?

\section{METHODOLOGY}

Considering the goal of the research that is studying the relationship among test anxiety, epistemological beliefs and problem solving among students, descriptive research method of correlative type was used. The society under study is all the male and female students of Sistan and Baluchestan University in Iran in 2013-2014 academic year. The total number of students was 19750 including 7900 male students and 11850 female students. About 13825 students were studying at Bachelor's degree and 5925 at Master's degree. The statistical sample was estimated using the table to determine the sample size of Kerjesi and Morgan (1970) and the method of sampling that was used was simple classified and random method. Out of 375 sample students, 225 were female ones and 150 were male ones. The number of the students studying at Bachelor's degree was 283 out of which 170 were female and 113 were male and 92 students were studying at Master's degree out of which 55 were female and 32 were male. The students studied at three faculties of fundamental sciences, engineering and technical and humanities.
In order to collect the data, three questionnaires of test anxiety developed by Abolqasemi, et al. (1996), epistemological beliefs developed by Schommer (1998) and problem-solving developed by Patio (2002) were used in Likert's spectrum of four choices (ranging from strongly disagree $=1$ to strongly agree $=4$ ) were used. The reliability of the questionnaires was calculated by Cronbach's Alpha test showing 0.93, 0.75 and 0.88 respectively. The details of the reliability of questionnaires are given in Table 1.

To analyze the data statistically, single sample t-test, independent $t$ and Pearson' correlative coefficient were adopted using SPSS software, version 20.

\section{RESULTS}

- What is the situation of students as far as test anxiety is concerned?

The results are shown in Table 2. The mean of the investigate students' marks was 61.50 as far as test anxiety variable was concerned which is less than the speculated mean (t-value), but single-variable t-test shows that the observed difference in means are not significant statistically and that generally speaking, students show relatively high test anxiety.

Table 2. Students' Test Anxiety status ( $\mathrm{n}=375)$

\begin{tabular}{ccccccc}
\hline Variable & Mean & $\begin{array}{c}\text { Criterion } \\
\text { Deviation }\end{array}$ & $\begin{array}{c}\text { t- } \\
\text { value }\end{array}$ & T & df & Sig \\
\hline $\begin{array}{c}\text { Test } \\
\text { Anxiety }\end{array}$ & 61.50 & 15.45 & 62.5 & 1.239 & 374 & 0.2106 \\
\hline
\end{tabular}

- What is the situation of students as far as epistemological beliefs are concerned?

The results of Table 3 show that due to significance level of aspects of simplicity of knowledge, certainty of knowledge and inherent ability by learn and knowing ability of everything which are lower than 0.05 , they are significant and since the obtained mean of the studied students' marks in this aspect is higher than the speculated mean (t-value) in the questionnaire, they are at desirable situation, but as far as rapid learning ability is concerned, the significance level is higher than 0.05 which is not significant. Generally speaking, the obtained mean of students' marks in the area of epistemological beliefs (88.38) was higher than the imagined mean (t-value) in the questionnaire and this difference is meaningful as far as the calculated $t$ (20.18) is concerned. Thus statistically speaking, it could be concluded that there is generally a suitable situation as far as epistemological beliefs area is concerned. 
Table 3. Students' Epistemological beliefs status ( $\mathrm{n}=375)$

\begin{tabular}{ccccccc}
\hline Category & Mean & St.D & T value & T & df & Sig \\
\hline Simplicity of knowledge & 23.00 & 2.76 & 20 & 21.10 & 374 & 0.001 \\
\hline Certainty of knowledge & 19.39 & 2.68 & 17.5 & 13.64 & 374 & 0.001 \\
\hline Inherent ability to learn & 19.53 & 3.49 & 17.5 & 11.26 & 374 & 0.001 \\
\hline Ability to know about everything & 14.20 & 2.42 & 12.5 & 13.54 & 374 & 0.001 \\
\hline Ability to learn quickly & 12.26 & 3.39 & 12.5 & -1.36 & 374 & 0.174 \\
\hline Total & 88.38 & 8.03 & 80 & 20.18 & 374 & 0.001 \\
\hline
\end{tabular}

Table 4. Students' Problem-solving status $(\mathrm{n}=375)$

\begin{tabular}{ccccccc}
\hline Category & Mean & St.D & T value & T & df & Sig \\
\hline Clarification of issue & 20.73 & 4.21 & 17.5 & 14.84 & 374 & 0.001 \\
\hline Production of ideas & 24.21 & 4.52 & 22.5 & 7.31 & 374 & 0.001 \\
\hline Development of solutions & 20.43 & 3.51 & 17.5 & 16.10 & 374 & 0.001 \\
\hline Implementation of programs & 19.68 & 2.70 & 17.5 & 15.58 & 374 & 0.001 \\
\hline Total & 85.05 & 11.98 & 75 & 16.23 & 374 & 0.001 \\
\hline
\end{tabular}

Table 5. Pearson Correlative index test among test anxiety, Epistemological beliefs and problem-solving ( $\mathrm{n}=375)$

\begin{tabular}{|c|c|c|c|c|}
\hline Variables & & Test Anxiety & Epistemological beliefs & Problem-solving \\
\hline \multirow{2}{*}{ Test Anxiety } & $\mathrm{R}$ & 1 & $0.28 * *$ & -0.01 \\
\hline & Sig & - & 0.001 & 0.83 \\
\hline \multirow[t]{2}{*}{ Epistemological beliefs } & $\mathrm{R}$ & $0.28 * *$ & 1 & $-0.21^{* *}$ \\
\hline & Sig & 0.00 & - & 0.001 \\
\hline \multirow[t]{2}{*}{ Problem-solving } & $\mathrm{R}$ & -0.01 & 0.001 & 1 \\
\hline & Sig & 0.83 & $-0.21^{* *}$ & - \\
\hline
\end{tabular}

Table 6. Independent t-test among test anxiety, epistemological beliefs and problem-solving in students according to gender $(\mathrm{n}=375)$

\begin{tabular}{|c|c|c|c|c|c|c|c|}
\hline Variables & Groups & $\mathrm{N}$ & Mean & St.D & $\mathrm{T}$ & $\mathrm{df}$ & Sig \\
\hline \multirow[t]{2}{*}{ Test Anxiety } & Female & 224 & 35.93 & 14.83 & 0.87 & 373 & 0.06 \\
\hline & Male & 151 & 37.36 & 16.39 & & & \\
\hline \multirow[t]{2}{*}{ Epistemological Beliefs } & Female & 224 & 83.59 & 6.89 & -0.42 & 373 & 0.57 \\
\hline & Male & 151 & 83.28 & 7.38 & & & \\
\hline \multirow[t]{2}{*}{ Problem-Solving } & Female & 224 & 84.87 & 12.62 & 0.34 & 373 & 0.13 \\
\hline & Male & 151 & 85.30 & 11.00 & & & \\
\hline
\end{tabular}

- What is the situation of students as far as problem solving is concerned?

The results of Table 4 show that due to the significance level in all aspects, the situation of problem-solving is lower than 0.05 . This is significant and since the obtained mean of the studied students' marks in this aspect is higher than the speculated mean (t-value) in the questionnaire, they are at a desirable situation. Thus statistically speaking, it could be concluded that there is generally a suitable situation as far as students' problem solving is concerned.

- Is there a significant relationship among text anxiety, epistemological beliefs and problem solving?

Table 5 shows the results of Pearson's correlative coefficient that demonstrate a positive and significant, although low, relationship between test anxiety and epistemological beliefs. But there is statistically no significant relationship between text anxiety and problem solving. Meanwhile the results showed that there is a negative and significant relationship at low level between epistemological beliefs and problem solving.

- Is there a difference among text anxiety, epistemological beliefs and problem solving as far as gender, age, major and educational degree are concerned?

A. Test anxiety test, epistemological beliefs and problem solving according to the students' gender

As the findings of Table 6 show, due to the significant level of text anxiety, the epistemological beliefs and problem-solving are higher than 0.05 which is not significant, thus there is statistically no difference among students as far as the variables of test anxiety, epistemological beliefs and problem-solving according to demographical characteristics of different genders are concerned.

B. Test anxiety test, epistemological beliefs and problem solving according to the students' age 
The results of Table 7 indicate the significance level in test anxiety and epistemological beliefs is higher than 0.05 which is not significant, it could be said statistically therefore there is no significant difference between the variables of test anxiety and epistemological beliefs as far as the students' age is concerned, but due to the fact that the significance level of problem-solving is lower than 0.05 which is significant, it could be statistically said that there is a significant difference among students as far as the students' age is concerned as the age group between 26 and 32 forms the highest mean and the age group between 22 and 25 forms the lowest mean. This indicates that the ability to solve problems is higher in the age group between 26 and 32 and is lower in the age group between 22 and 25.

The findings of Table 8 indicate that there is a significant difference among students in the age group between 26 and 32 as far as problem-solving variable is concerned and there is a significant difference in the mean difference (-4.65) at 99\% level $(p<0.01)$. Also there is a significant difference among students in the age group between 22 and 25 with mean difference (4.65) at $99 \%$ level $(p<0.01)$.

C. Test anxiety test, epistemological beliefs and problem solving according to the students' major

The results of Table 9 indicate the significance level of test

Table 7. Variance Analysis Test of test anxiety, epistemological beliefs and problem-solving in students according to age $(\mathrm{n}=375)$

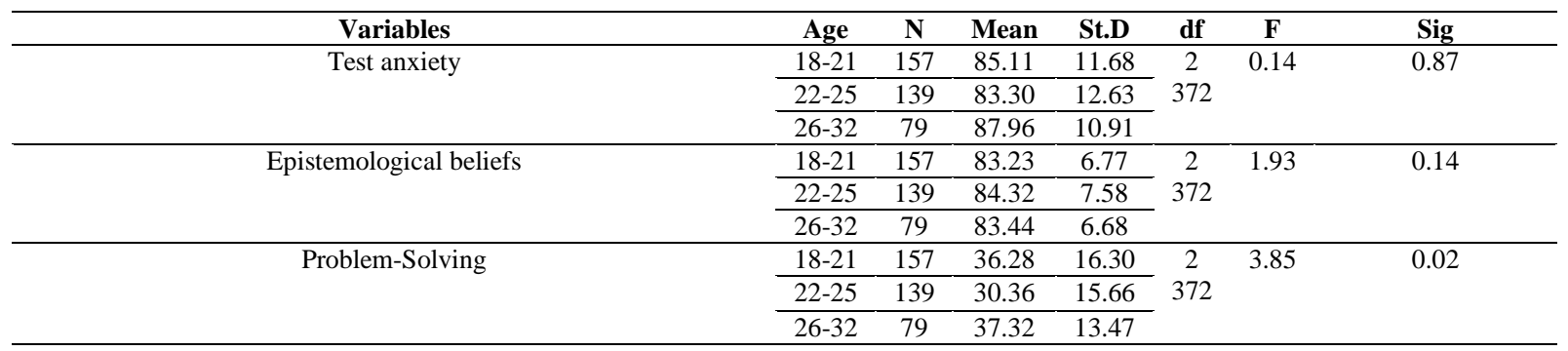

Table 8. Results of Tukey test to solve problem according to age $(n=375)$

\begin{tabular}{|c|c|c|c|c|c|}
\hline Variable & Age (I) & Age) J( & Mean difference (I-J) & Standard error & Sig \\
\hline \multirow{6}{*}{ Problem-solving } & \multirow[t]{2}{*}{$18-22$} & $22-25$ & 1.80 & 1.38 & 0.58 \\
\hline & & $26-32$ & -2.84 & 1.64 & 0.25 \\
\hline & \multirow[t]{2}{*}{$22-25$} & $18-22$ & -1.80 & 1.38 & 0.58 \\
\hline & & $26-32$ & $-4.65^{*}$ & 1.67 & 0.01 \\
\hline & \multirow[t]{2}{*}{$26-32$} & $18-22$ & 2.84 & 1.64 & 0.25 \\
\hline & & $22-25$ & $4.65^{*}$ & 1.67 & 0.01 \\
\hline
\end{tabular}

Table 9. Variance Analysis Test of test anxiety, epistemological beliefs and problem-solving in students according to major (The number is 375)

\begin{tabular}{|c|c|c|c|c|c|c|c|}
\hline Variables & Major & $\mathbf{N}$ & Mean & Standard deviation & df & $\mathbf{F}$ & Sig \\
\hline \multirow[t]{3}{*}{ Test Anxiety } & $\begin{array}{l}\text { Engineering \& Techni- } \\
\text { cal }\end{array}$ & 107 & 40.61 & 16.39 & \multirow[t]{3}{*}{$\begin{array}{c}2 \\
372\end{array}$} & \multirow[t]{3}{*}{0.23} & \multirow[t]{3}{*}{0.79} \\
\hline & Humanities & 176 & 62.02 & 14.21 & & & \\
\hline & Fundamental Sciences & 92 & 60.66 & 16.78 & & & \\
\hline \multirow[t]{3}{*}{ Epistemological beliefs } & $\begin{array}{l}\text { Engineering \& Techni- } \\
\text { cal }\end{array}$ & 107 & 88.02 & 8.31 & \multirow[t]{3}{*}{$\begin{array}{c}2 \\
372\end{array}$} & \multirow[t]{3}{*}{0.19} & \multirow[t]{3}{*}{0.82} \\
\hline & Humanities & 176 & 88.63 & 7.71 & & & \\
\hline & Fundamental Sciences & 92 & 88.33 & 8.38 & & & \\
\hline \multirow[t]{3}{*}{ Problem-Solving } & $\begin{array}{l}\text { Engineering \& Techni- } \\
\text { cal }\end{array}$ & 107 & 86.05 & 11.88 & \multirow[t]{3}{*}{$\begin{array}{c}2 \\
372\end{array}$} & \multirow[t]{3}{*}{2.09} & \multirow[t]{3}{*}{0.12} \\
\hline & Humanities & 176 & 83.71 & 12.72 & & & \\
\hline & Fundamental Sciences & 92 & 86.43 & 10.38 & & & \\
\hline
\end{tabular}

Table 10. Independent t-test among test anxiety, epistemological beliefs and problem-solving in students according to degree of study ( $\mathrm{n}=375$ )

\begin{tabular}{|c|c|c|c|c|c|c|c|}
\hline Variables & Groups & $\mathbf{N}$ & Mean & Criterion deviation & $\mathbf{T}$ & df & Sig \\
\hline \multirow[t]{2}{*}{ Test Anxiety } & Bachelor's degree & 281 & 61.67 & 16.03 & 0.34 & 373 & 0.17 \\
\hline & Master's degree & 94 & 61.03 & 13.73 & & & \\
\hline \multirow{2}{*}{$\begin{array}{l}\text { Epistemological } \\
\text { beliefs }\end{array}$} & Bachelor's degree & 281 & 88.57 & 8.04 & -0.76 & 373 & 0.52 \\
\hline & Master's degree & 94 & 87.83 & 8.04 & & & \\
\hline \multirow[t]{2}{*}{ Problem- solving } & Bachelor's degree & 281 & 84.30 & 12.11 & -2.08 & 373 & 0.56 \\
\hline & Master's degree & 94 & 87.27 & 11.36 & & & \\
\hline
\end{tabular}


anxiety and epistemological beliefs is higher than 0.05 which is not significant, it could be statistically said that there is a significant difference among students' variables of test anxiety and epistemological beliefs as far as the students' major is concerned.

D. Text anxiety, epistemological beliefs and problem solving according to students' educational degree

As the findings of Table 10 show, since the significant level of test anxiety, epistemological beliefs and problem-solving is higher than 0.05 which is not significant, it could statistically be said that there is not a significant relationship among the students' text anxiety, epistemological beliefs and problemsolving as far as the students' educational degree is concerned.

\section{DISCUSSION AND CONCLUSIONS}

The study aimed to investigate the relationship among test anxiety, epistemological beliefs and problem solving in students of Sistan-Balouchestan University. Since the goal of the current research is to study the test anxiety, epistemological beliefs and problem-solving among the students of Sistan-Balouchestan University, the obtained findings showed that the students are not at a suitable situation as far as test anxiety is concerned and generally speaking, the students have relatively high test anxiety. It was proved that they show high level of epistemological beliefs (aspects of simplicity of knowledge, certainty of knowledge, inherent ability and ability to know everything) and show low level of rapid learning ability aspect. Generally speaking, they are at a suitable situation as far as epistemological beliefs are concerned. They show high level of problem solving (to clarify the problem, to produce ideas, to develop solutions and to implement programs) and generally speaking, they are at a suitable situation as far as the students' problem solving is concerned. There is also a significant relationship between test anxiety and epistemological beliefs. The Study conducted by Spada, Georgiou and Wells (2009) discovered the relationship between infra-cognition and text anxiety and the results showed a positive relationship and correspondence between some of the infra-cognition aspects and text anxiety. Meicheng et al. (2009) found out in their study that was conducted by two qualitative and quantitative methods at the last year of Bachelor's degree of teachers' pre-service education aiming to study and test 'the relationship between epistemological beliefs of teachers and comprehension of the educational concepts and learning' that most of the students believe that making attempts to learn (solve problems) is more important that the individual's inherent ability. In fact the changes of knowledge cause the mental skills to grow and knowledge certainty is effective to reinforce epistemological beliefs that correspond with our study. But there is no significant relationship between test anxiety and problem solving. Also there is no significant relationship among variables of test anxiety, epistemological beliefs and problem-solving as far as the demographical characteristics including gender, major and educational degree among students were concerned, while there is a significant difference with regard to the variable of problemsolving as far as age is concerned.

Test anxiety threatens the students' psychological health and affects their efficiency, emergence of talent, formation of personality and social identity negatively and as an overall phenomenon that creates problems among university and school students could have negative effect on their educational progress and optimal performance, particularly when it comes to assess them. Several factors such as personality characteristics are effective to reduce or create test anxiety. According to the obtained results, it is recommended that the advising professors in cooperation with students' consultation centre as well as the group of psychologists try to take the necessary actions to reduce and control the students' test anxiety. Also problem-solving could empower the individuals to adopt effective and settled strategies to confront the daily problems. In other words, problem solving is an important conflicting strategy that could increase the ability, personal and social progress and reduce the chaos and psychological symptoms. It goes without saying that teaching the skills to solve problems could be considered as a valuable service to the young generation. It is necessary for the ones in charge, programmers of educational problems to take methods to compile educational programs required for the students into consideration so that they could make their confronting methods efficient and effective with regard to the problems in general and to the test anxiety in particular, and to strengthen the students not to feel unable or disappointed when facing problems, but to be able to empower themselves to confront every difficulty. Also considering the importance of epistemological beliefs in educational variables including educational advancement, educational incentive, educational target selection, etc., it seems that it is necessary to consider some training for students in this regard so that changes to their epistemological beliefs could change their learning process and methods.

\section{STUDY LIMITATIONS}

As the data collection measure is questionnaire in this research, it is including all the limitations of this study measure. Other actions including interview, observation can increase the reliability of results. The limitations of the studies are similar to the present subject in Iran and the lack of comparison of the findings with the results of other researchers.

\section{REFERENCES}

Abolqasemi, A., Asaadi-Moghadam, A., Najariyan, B., \& Shokrkon, H. (1996). Construction and navigation validated scale to measure anxiety. Quarterly Journal of Educational Science and Psychology, 3(3-4), 61-74.

Aksan N., \& Sozer, M. A. (2007). The Relationships Among Epistemological Beliefs and Problem Solving Skills of University Students. Journal of Kirsehir Education Faculty, 8(1), 31-50.

Hannon, B. (2012). Test anxiety and performance-avoidance goals explain gender differences in SAT-V, SAT-M, and overall SAT scores. Personality and Individual Differences, 53(7), 816-820. doi: 10.1016/j.paid.2012.06.003

Conley, A. M., Pintrich, P. R., Vekir, I., \& Harrison, D. (2004). Changes in epistemological beliefs in elementary science students. Contemporary educational psychology, 29(1), 189-204.

Erdem, E. (2007). Study of the relationship between test anxiety and the epistemological and problem solving beliefs of students on a general chemistry course. World Applied Sciences Journal, 2(5), 750-758.

Fathi-Ashtiani, A., \& Imam Qolivand, F. (2002). Comparison between methods of cognitive therapy and regular sensitivity removal in reducing test anxiety. Kowsar Medical Journal, 7(3), 245-251.

Fathi-Ashtiyani, A., \& Emam Gholivand, F. (2002). Comparison of cognitive therapy and systematic desensitization in reducing test anxiety. Kowsar Medical Journal, 7(3), 245-251.

Filisetti, L. (2003, april). The French Connections: Examining the Links among Epistemological Beliefs, Goal Orientations and Self-Efficacy. In H. Fives (Chair), Internationalizing the study of Epistemology, Goal orientations, and Self-efficacy. Paper presented at the annual meeting of the American Educational Research Association, Chicago. 
Glover, J. A., \& Bruning, R. H. (2001). Educational Psychology (its principles and applications). Kharrazi, Tehran: University Publication Center.

Gholami-Lavasane, M., Mellat, N., \& Karamatdost, N. A. (2009). The role of Epistemological Beliefs, Information Processing Strategies and Motivational Constructs in Regulation of Learning. Journal of Psychology and Education, 39(3), 47-67.

Hofer, B. K. (2000). Dimensionality and disciplinary differences in personal epistemology. Contemporary Educational Psychology, 25(4), 378-405. doi: 10.1006/ceps.1999.1026

Hofer, B. K., \& Pintrich, P. R. (1997). The development of epistemological theories: Beliefs about knowledge and knowing and their relation to learning. Review of Educational Research, 67(1), 88-140. doi: 10.3102/00346543067001088

Kardash, C. A. M., \& Scholes, R. J. (1996). Effects of preexisting beliefs, epistemological beliefs, and need for cognition on interpretation of controversial issues. Journal of Educational Psychology, 88(2), 260-271. doi: 10.1037/00220663.88.2.260

King, P. M., \& Kitchener, K. S. (1994). Developing Reflective Judgment: Understanding and Promoting Intellectual Growth and Critical Thinking in Adolescents and Adults. San Francisco: Hossey-Bass.

Kivimaki, M. (1995). Test anxiety, below capacity performance: Intra subject approach with violin student. Pers Individ Dif., 18(1), 47-56. doi: 10.1016/0191-8869(94)00115-9

Koksal, M. S. (2011). Epistemological Predictors of "Self Efficacy on Learning Biology" and "Test Anxiety Related to Evaluation of Learning on Biology" for Pre-Service Elementary Teachers. Journal of Science Teacher Education, 22(7), 661-677. doi: 10.1007/s10972-010-9205-0

Mandler, G. \& Sarason, S. B. (1952). A study of anxiety and learning. J. Abnormal \& Soc. Psychol, 47(1), 166-73. doi: 10.1037/h0062855

Mehrabizadeh-Honarmand, M., Abolqasemi, A., Najjarian, B., \& Shekarkan, H. (2000). Study of the degree of epidemiology of test anxiety on the relation of self-efficiency and the way to control it considering the variable of intelligence. Educational Sciences and Psychology Journal of Shahid Chamran University, $7(1-2), 55-72$.

Meyers, C. (2004). Education of critical thought. Tehran: Samt Publication.

Oh, S., \& Jonassent, D. H. (2007). Scaffolding online argumentation during problem solving. Journal of Computer Assisted Learning, 23(2), 95-110. doi: 10.1111/j.1365-2729.2006.00206.x

Öngen, D. (2003). The relationship between epistemological beliefs and problem solving strategies: A study on students of faculty of education. Journal of Educational Research, 3(13), 155-162.

Perry, W. G. (1981). Cognitive and ethical growth: The making of meaning in a checkering. In A. Checkering (Ed.), The modern American college. San Francisco: JosseyBass.

Ravindran, B., Grene, B. A., \& Debacker, T. K. (2000). Predicting preservice teachers' cognitive engagement with goals and epistemological beliefs. Department of Educational Psychology, pp. 22-32.

Sargolzaei, M., Fayazi-Bordbar, M., Samari, A. \& Shakiba, M. (2003). Behavioral cognitive approach and planning of nervous speech to control test anxiety. Principles of Psychological Health Quarterly, 34(17-18), 47.

Schommer, M. (1998). The influence of age and schooling on epistemological beliefs. British Journal of Educational Psychology, 68(4), 551-562. doi: 10.1111/j.2044-8279.1998.tb01311.x

Schommer, M. (1993). Comparisons of beliefs about the nature of knowledge and learning among postsecondary students. Research in Higher Education, 3, 355-370. doi: 10.1007/BF00991849

Schommer, M. (1990). Effects of Beliefs about the Nature of Knowledge on Comprehension. Journal of Educational Psychology, 82(5), 498-504. doi: 10.1037/0022-0663.82.3.498

Shaabani, H. (2003). Advanced Teaching Method. Tehran.

Shahbazi, S., Heidari, M., \& Ali-Sheikhi, R. (2011). Effect of teaching problemsolving skill on the degree of tolerating stress in nursing students. Shahrekurd University of Medical Sciences Journal, 13(2), 32-37.

Sobhi-Qaramaleki, N., Rasoulzadeh-Tabatabaei, K., Azad-Fallah, P., \& Fathi Ashtiani, A. (2008). Study of effectiveness of cognitive therapy and teaching of studying skills to treat students suffering from test anxiety. Scientific and Research Psychological Quarterly, 3(11).

Spada, M. M., Georgiou, G., \& Wells, A. (2009). The relationship among metacognitions, attentional control and state anxiety. Cognitive Behaviour Therapy, 39(1), 64-71. doi: 10.1080/16506070902991791

Stober, J., \& Pekrun, R. (2004). Advances in Test Anxiety. Research Anxiety, Stress and Coping, 17(3), 205-211. doi: 10.1080/1061580412331303225

Yeo-Kai-Kow, J. (2005). Anxiety and Performance on Mathematical Problem Solving of Secondary Two Students in Singapore, The Mathematics Educator, $8(2), 71-83$.
Yousefi, F., Habibi, S., \& Mohammadkhani, M. (2013). The degree of test anxiety on medical students and its relation with gender. Educational strategies in medical sciences, 6(3). 